\title{
Influence of temperature and germination time on diastatic power of blue and red maize (Zea mays $L$.) malts
}

\author{
Miguel Ángel Hernández-Carapiaa, Héctor Bernardo Escalona-Buendíab, José Ramón Verde-Calvo * \\ ${ }^{a}$ Enology and Fermented Food Laboratory, Biotechnology Departament, Universidad Autónoma Metropolitana, Av. San Rafael Atlixco No. 186, \\ 09340. Mexico City, Mexico, 'bSensory and Consumer Laboratory, Biotechnology Departament, Universidad Autónoma Metropolitana, Av. San \\ Rafael Atlixco No. 186, 09340. Mexico City, Mexico
}

\section{A B S TR A C T}

\begin{abstract}
Maize endosperm consists of about $70 \%$ starch, which makes it an excellent substrate for fermentation. However, due to its low diastatic power, it is used in brewing as an adjunct, mainly. In order to include both red and blue maize as an enzyme source in the brewing process, the effect of temperature and time germination on the diastatic power of malts was studied. The research consisted in a completely randomized three-factor experimental design where the involved factors were colour of maize (blue and red), germination temperature $\left(15,20\right.$, and $\left.25^{\circ} \mathrm{C}\right)$, and germination time $(3,4,5,6,7,8$, and 9 days). The response variables were germination percentage, acrospire length, malting yield, and diastatic power. Data was analysed through Analysis of variance and Comparison Multiple Tukey's Test. Results showed that both temperature and germination time encouraged the acrospire length, which had a negative effect on malting yield. Regarding to diastatic power, it maintained an increase from third to seventh germination day, at the three tested temperatures. Additionally, as the germination temperature increased, the diastatic power also increased. The highest diastatic power for blue and red maize malts were 39 and $42{ }^{\circ} \mathrm{L}$, respectively, and it was reached when these malts were germinated for 7 days at $25{ }^{\circ} \mathrm{C}$. It was concluded that, by germinating both blue and red maize under the resulting optimum conditions, the obtained malts would be capable of converting their own starch.
\end{abstract}

Keywords: Blue and red maize; Diastatic power; Germination temperature; Germination time; Malting yield

\section{INTRODUCTION}

Malting is a controlled germination of grains in moist air, and the process can be divided into three stages: steeping, with which the acquiescent grain imbibes water and hydrates the embryo and endosperm; germination, by which enzymes are synthesized, activated, and mobilized, and the embryo begins to develop; finally, kilning, wherewith grain growth is halted using a heat treatment, which dries the grain to constant and low moisture for storage. The aims of germination, among others, are to convert or modify the physical structure of the grain and allow synthesis or activation of a series of enzymes (MacLeod \& Evans, 2016). Diastatic power is the combined activities of $\alpha$-amylase, $\beta$-amylase, limit dextrinase, and $\alpha$-glucosidase, which solubilize starch to fermentable sugar during malting (Ribeiro Jr et al., 2016). In other words, diastatic power is a measure of how effective the malt is at converting starch to sugar (Farber \& Barth, 2019), and is an important quality trait for malt used in brewing and distilling (Looseley et al., 2017).

There are different methods to measure diastatic power. Among them, the rapid Henry's method (Henry, 1984), which is characterized by both using a little quantity of sample and being a quick method compared to either American Society of Brewing Chemists (ASBC) or the Institute of Brewing (IoB) method.

Barley is the most preferred grain for brewing all over the world, among other things, due to its high diastatic power. However, if it is considered that the endosperm of maize consists of approximately $70 \%$ starch embedded in a protein matrix, this cereal is an excellent substrate for

\footnotetext{
${ }^{*}$ Corresponding author:

José Ramón Verde-Calvo, Enology and Fermented Food Laboratory, Biotechnology Departament, Universidad Autónoma Metropolitana, Av. San Rafael Atlixco No. 186, 09340. Mexico City, Mexico. E-mail: jrvc@xanum.uam.mx
} 
fermentation (Chaudhary et al., 2014). For this reason, maize has been used since time immemorial as part of the carbohydrate material in beer brewing, but mainly as an adjunct prepared in different forms such as flakes, grits, and flour (Iwouno \& Ojukwu, 2012), due to its little diastatic power (Meußdoerffer \& Zarnkow, 2009).

In México there are a broad diversity of maize, and at least 59 races have been described (Vielle-Calzada \& Padilla, 2009), among them the 'Chalqueño' race, which has variations in grains colour such as white, yellow, blue, and red (Herrera-Cabrera et al., 2004), and predominates in the High Valleys of the Mexican Central Plateau for irrigation crops (Arellano-Vázquez et al., 2014).

For many years, malting of maize for using as a major source of hydrolytic enzymes required for brewing purposes has received little attention, but during the last years many researchers have focused their efforts on optimizing the maize malting process (Chaudhary et al., 2014). Their results have shown the influence of malting conditions such as steeping time, germination time or kilning temperature on the diastatic power. However, these works have been focused on white and yellow varieties, mostly (Eneje et al., 2004; Iwouno \& Ojukwu, 2012; Awoyinka \& Adebawo, 2008). As for both blue and red maize malts, several research projects about brewing with these malts have been carried out in the Universidad Autónoma Metropolitana, in México (Romero-Medina et al., 2020; Flores-Calderón et al., 2017). Also, a patent about the coloured-maize brewing process has been developed (Verde-Calvo et al., 2019); however, the diastatic power of the malts has not been reported. In addition to this, the coloured-maize beers reported in these projects had low alcohol content, about $2 \%$ and $3 \%$ alcohol by volume, which could be related to the poor diastatic power of the malts.

Considering all the above, and in order to include coloured maize as an enzyme source in the brewing process, a study of maize germination conditions was performed. The aims of this research were to study the influence of temperature and germination time on the diastatic power of maize malts, as well as to find the conditions under which the malts have the highest diastatic power.

\section{MATERIALS AND METHODS}

\section{Sample purchase and preparation}

The maize used in this experiment were both blue and red colour of the Mexican race 'Chalqueño', purchased from a local producer in Milpa Alta, Mexico City. The maize of each colour was separately selected to eliminate those kernels that looked like having either mechanical or microbiological damage.

\section{Proximate composition}

The methods used to perform the proximate composition of red and blue maize were those stipulated by the Mexican norms named in Table 1.

\section{Weight of 1000 kernels}

One thousand kernels of each colour of maize were randomly selected, taken in by hand, and weighted on an analytic balance (Explorer Ohaus, Switzerland) as reported by Deivasigamani and Swaminathan (2018). This process was made in triplicate for each colour of maize.

\section{Germination}

For the germination experiment, a completely randomized three-factor experimental design was used. The involved factors were colour of maize (red and blue), germination temperature, and germination time. The experiment was performed as follows: all maize of the same colour was steeped together and at once in fresh water (at a rate of 1:2, maize: water). The steeping lasted for 42 hours (Iwouno \& Ojukwu, 2012), at room temperature $\left(18-25^{\circ} \mathrm{C}\right)$. During the steeping time, the water was drained every 12 hours and the maize had dry periods of 3 hours to allow oxygenation. After this, the soaked maize was distributed among experimental units (EU), which each one consisted of $150 \mathrm{~g}$ of soaked maize placed inside a clear hingedlid plastic container whose both bottom and roof were previously prepared with a layer of wet paper. Along the germination time, the maize was aspersed with fresh water every 12 hours to keep the moisture of the kernels; also, it was aerated every 8 hours to remove the heat formed by grains metabolism. The germination was carried out at three different temperatures: 15,20 , and $25^{\circ} \mathrm{C}$ for $3,4,5$, $6,7,8$, and 9 days. Every treatment was made in triplicate, thus having a total of $126 \mathrm{EU}$. All of EU corresponding to the same temperature were put inside an environmental chamber (Scorpion Scientific, Mod. 50620-IL), at $80 \%$ of humidity and in light absence, where remained until their germination time was fulfilled. Once it occurred, the percentage of sprouted kernels and the length of acrospires

Table 1: Methods used to perform the proximate composition of maize

\begin{tabular}{lc}
\hline PARAMETER & METHOD \\
\hline Moisture (\%) & NOM-116-SSA1-1994 \\
Crude fibre (\%) & NMX-F-613-NORMEX-2017 \\
Crude protein (\%) & NMX-F-608-NORMEX-2011 \\
Crude fat (\%) & NOM-086-SSA1-1994 \\
Ash (\%) & NMX-F-607-NORMEX-2013 \\
Total carbohydrate (\%) & Calculated by difference \\
& (Ramdath et al., 2020) \\
Reducing sugar (\%) & NOM-086-SSA1-1994 \\
\hline
\end{tabular}


were determined. After that, radicles and acrospires were removed from the kernels before being kilned, so as these did not interfere on the drying process, and then all kernels of the correspondent EU were put inside a drying oven at $55^{\circ} \mathrm{C}$ for 24 hours to stop their germination process (Iwouno \& Ojukwu, 2012). Finally, the malt yield of each EU was calculated.

\section{Determination of the sprouted kernels percentage}

Once the germination time was fulfilled, the correspondents EU were removed from the germination chamber and the sprouted and non-sprouted grains in each EU was counted to calculate the germination percentage, as reported by Saba et al. (2014), by using the next formula:

$$
G P=\frac{S}{T} \times 100
$$

Where:

$G P=$ percentage of sprouted grains

$S=$ number of sprouted grains

$T=$ total number of grains

\section{Determination of acrospire length}

The determination of acrospire length was performed as reported by Dahiya et al. (2018). In each EU, acrospire was measured by taking the average of sprout length of twelve grains which were randomly selected, from base to tip, using a cotton rope because of the irregular shape of the acrospire.

\section{Malting yield}

Once dried, the malted grains (all grains, the sprouted and non-sprouted) were weighted on an analytic balance. To calculate the malting yield, a five-point linear calibration curve was built in order to know how many grams of raw maize were equal to the 150 grams of soaked maize used to perform the germination experiment. This curve was made using 90, 100, 110, 120, and $130 \mathrm{~g}$ of raw maize, which were separately soaked, and in the same conditions as the maize used for the germination experiment. The malting yield calculation was performed by using the next formula as described by Odo et al. (2016):

$$
\% M y=\frac{M w}{m w} \times 100
$$

Where:

$\% M y=$ percentage of malting yield

$M w=$ dried malt weight (in grams)

$m w=$ raw maize weight (in grams)

\section{Correlation between the acrospire length and malting loss}

A linear calibration was built to calculate the rate of malting loss, as the dependent variable (y), due to the acrospire growth, as the independent variable (x). The curve was built by using the two mentioned response variables of each EU, and the correlation was calculated by using the Pearson's correlation.

\section{Diastatic power}

Henry's method

The Henry's method (Henry, 1984) with some modifications was used for measuring diastatic power of the experimental maize malts.

\section{Reagents}

Buffered starch solution, sodium hydroxide solution, p-hydroxybenzoic acid hydrazide solution (PAHBAH), and ammonium hydroxide solution were prepared as described for Henry (Henry, 1984). All reagents used were analytical grade.

\section{Enzyme extraction}

$10 \mathrm{~g}$ of maize malt was ground in a manual fluted-discgrain-grinder in such way that it passed through a 0.84 sieve. $0.0250 \mathrm{~g}$ of ground malt was directly weighted into a plastic centrifuge tube. $5 \mathrm{ml}$ of $6 \mathrm{mM}$ ammonium hydroxide was added and manually mixed by gentle swirling. This mixture was incubated in a water bath at 25 ${ }^{\circ} \mathrm{C}$ for $10 \mathrm{~min}$ and then centrifugated at $2500 \mathrm{~g}$ (Solbat, Mexico) for $3 \mathrm{~min}$.

\section{Diastasis}

$0.2 \mathrm{ml}$ of enzyme extract was added to a $30 \mathrm{ml}$ Pirex glass test tube containing $20 \mathrm{ml}$ of a $2 \% \mathrm{w} / \mathrm{v}$ soluble starch solution buffered to $\mathrm{pH}=4.6$. It was let stand for $10 \mathrm{~min}$ at $20^{\circ} \mathrm{C}$ for starch digestion. After this time, the digestion was stopped by adding $1.2 \mathrm{ml}$ of $0.5 \mathrm{M}$ sodium hydroxide.

\section{Blank correction}

To prepare the blank correction solution, $1.2 \mathrm{ml}$ of $0.5 \mathrm{M}$ sodium hydroxide was added to $0.2 \mathrm{ml}$ of enzyme extract before the addition of the starch solution. The blank solution was treated in the same way as the starch solution undergoing diastasis.

\section{Determination of reducing sugars}

$0.2 \mathrm{ml}$ of the digested starch solution was added to a $20 \mathrm{ml}$ Pirex glass test tube containing $5 \mathrm{ml}$ of $0.5 \% \mathrm{w} / \mathrm{v}$ PAHBAH, it was mixed and immersed in a boiling water bath for exactly $4 \mathrm{~min}$. After this time, the tube was removed from the boiling water bath and placed in a $20^{\circ} \mathrm{C}$ water bath for $10 \mathrm{~min}$. Then, $10 \mathrm{ml}$ of distilled water was added to the tube and mixed by vortexing. The blank solution was treated in the same way. Finally, absorbance was read at $415 \mathrm{~nm}$ (Thermo Spectronic, Mod. BioMate3, USA), and reducing sugars were calculated by using a dextrose calibration curve. Diastatic power by Henry's method was reported as mg of dextrose/l.

Emir. J. Food Agric • Vol 33 •Issue 1 • 2021 
Linear calibration for diastatic power determination Due to diastatic power of commercial malts is mainly reported either in Lintner $\left({ }^{\circ} \mathrm{L}\right)$ or Windisch-Kolbach $\left({ }^{\circ} \mathrm{WK}\right)$ degrees as well as the minimum diastatic power for malt to convert its own starch is reported in ${ }^{\circ} \mathrm{L}$, when the Henry's method is used to measure diastatic power it is advisable to convert the Henry's units into ${ }^{\circ} \mathrm{L}$ or ${ }^{\circ} \mathrm{WK}$ to know, according to the literature, if the malts are suitable for brewing. For this reason, analogously to the recommendation of the ASBC (ASBC, 2004), a linear calibration of the Henry's method was made to convert the Henry's method units into Lintner degrees, instead of ASBC degrees. To make this, the diastatic power of seven different malts, from maize, wheat, rye, and barley were determined, in duplicate, through the Henry's method (as described for the maize malts) as well as the IoB method (Anon,1982) with some modifications.

\section{Institute of brewing method \\ Reagents}

Buffered starch solution, sodium hydroxide solution, Fehling's solutions, and ammonium hydroxide solution were prepared as described for the IoB (Anon, 1982). All reagents used were analytical grade.

\section{Enzyme extraction}

$11 \mathrm{~g}$ of maize malt was ground in a manual fluted-discgrain-grinder and $10 \mathrm{~g}$ of this ground malt was directly weighted into a $500 \mathrm{ml}$ glass beaker. $200 \mathrm{ml}$ of $6 \mathrm{mM}$ ammonium hydroxide was added and manually mixed by gentle swirling. Then, the mixture was incubated for $2.5 \mathrm{~h}$ in a water bath at $20^{\circ} \mathrm{C}$ with stirring every half hour. After this time, a portion of this extract was taken and allowed the grains to settle for $30 \mathrm{~min}$.

\section{Starch digestion}

The required volume of the enzyme extraction liquid (from 1 to $20 \mathrm{ml}$, depending on the malt) was added to a $200-\mathrm{ml}$ flask containing $100 \mathrm{ml}$ of $2 \%$ buffered soluble starch solution, so that the quantity of digested starch solution needed to reduce $5 \mathrm{ml}$ of Fehling's solution was between 15 and $30 \mathrm{ml}$. The flask was shaken, and it was let to stand $1 \mathrm{~h}$ at $20^{\circ} \mathrm{C}$ for starch digestion. After this time, the digestion was stopped by adding $6 \mathrm{ml}$ of $0.5 \mathrm{~N}$ sodium hydroxide and made up to $200 \mathrm{ml}$ with distilled water at the same temperature.

\section{Titration of Fehling's solution}

$5 \mathrm{ml}$ of mixed Fehling's solution was pipetted into a 150-ml Erlenmeyer flask and added a volume almost sufficient of the digested starch solution to reduce the Fehling's solution. The content of the flask was mixed by swirling and heat until moderate ebullition over a ceramic hot plate, where was kept for $2 \mathrm{~min}$. Then, 3 drops of methylene blue were added and the titration was completed in one minute maintaining ebullition.

\section{Blank correction}

The undigested $2 \%$ starch solution was titrated against $2 \mathrm{ml}$ of mixed Fehling's solution as described in the "Titration of Fehling's solution" section.

\section{Diastatic power calculation}

Diastatic power of the malts was calculated by using the next formula:

$$
D . P .=\frac{2000}{x y}-\frac{200}{x s}
$$

Where:

D. P.= Diastatic power, expressed in IoB degrees $\left({ }^{\circ} \mathrm{IoB}\right)$ $\mathrm{x}=$ number of $\mathrm{ml}$ of malt extract taken for the digestion $\mathrm{y}=$ number of $\mathrm{ml}$ of the digested starch solution required for reduction of $5 \mathrm{ml}$ of Fehling's solution $\mathrm{s}=$ titre of starch blank

The ${ }^{\circ} \mathrm{IoB}$ obtained were converted into ${ }^{\circ} \mathrm{L}$ by using the formula reported by the European Brewery Convention (Home \& Sharpe, 2007):

${ }^{\circ} \mathrm{L}=\left({ }^{\circ} \mathrm{IoB}\right) * 1.1$

Results were expressed as ${ }^{\circ} \mathrm{L}$ to the nearest whole number.

Then, a linear calibration was performed by calculating the regression line equation for the data using the units obtained from the Henry's method (reducing sugars produced, reported as $\mathrm{g}$ of dextrose/l) as the independent variable $(\mathrm{x})$, and diastatic power $\left({ }^{\circ} \mathrm{L}\right)$ as the dependent variable $(\mathrm{y})$. The equation was used to determine the diastatic power of the maize malts in ${ }^{\circ} \operatorname{Lintner}$ (ASBC, 2004).

\section{Determination of diastatic power of the experimental maize malts}

As previously mentioned, the diastatic powers of the experimental malts were determined through the Henry's method. Finally, the obtained concentration units from this method were converted into ${ }^{\circ} \mathrm{L}$ by using the calibration curve equation.

\section{Data analysis}

The data obtained from the thousand-kernel weight was analysed through one-way ANOVA, where colour of maize was the only factor. The data obtained from the germination experiment (germination percentage, acrospire length, malting yield, and diastatic power) was analysed through both three-way ANOVA and Tukey's test by using the statistical software NCSS 2020 Version 20.0.3 (NCSS 2020 Statistical Software, 2020). 


\section{RESULTS AND DISCUSSION}

\section{Proximate composition}

As it is shown in Table 2, the proximate composition of both red and blue maize are similar and their values fall within those reported for other Mexican varieties of maize. For example, Peña-Betancourt et al. (2017) and SánchezMadrigal et al. (2014) reported values of $7.09 \%-10.16 \%$ of protein, $4.44 \%-5.81 \%$ of fat, and $1.28 \%-1.39 \%$ of ash for blue varieties. In the same way, Sánchez-Madrigal et al. (2014) reported $9.60 \%$ of moisture, $75.23 \%$ of carbohydrate, and $2.26 \%$ of crude fibre. With respect to red varieties, it was not found proximate composition reported for Mexican races, but Adeniyi and Ariwoola (2019) reported values of $1.29 \%$ and $2.24 \%$ of fat, $0.51 \%$ and $1.0 \%$ of ash, $12.82 \%$ and $9.32 \%$ of protein, $0.86 \%$ and $1.55 \%$ of crude fibre, as well as $71.48 \%$ and $74.40 \%$ carbohydrate for two red Nigerian maize varieties.

\section{Weight of 1000 kernels}

Results showed that the thousand-kernels weight of the blue and red maize were $548.6 \mathrm{~g}$ and $520.9 \mathrm{~g}$, respectively. So, in general, the blue ones were about $5.4 \%$ heavier than the red ones ( $\mathrm{p}$-value $=0.001)$, which indicates a larger size of the first ones. With respect to this Sulewska et al. (2014) reported the weight of three different fractions (small, medium, and large) of the 'Boruta' maize variety, and the thousand kernel weight of the large fraction was 410 g. Agama-Acevedo et al. (2011) reported the thousand kernel weight of different samples of bluegrain 'Chalqueño' race maize whose values were between 367.6 and $509.8 \mathrm{~g}$. These values indicate that this race of maize has larger grains in comparison to other varieties, as reported by Rocandio-Rodríguez et al. (2014), who stated that this race is characterized by having large and wide grains.

\section{Data analysis of the germination experiment}

Table 3 shows the ANOVA results of each response variables for the three factors involved in the germination experiment as well as the interactions. As it can be seen, only the interaction of maize colour (Maize) with germination days was no significant for both germination percentage and acrospire length.

$\begin{aligned} & \text { Table 2: Proximate composition of red and blue 'Chalqueño' } \\
& \text { race maize }\end{aligned}$
\begin{tabular}{|lcc}
\hline Parameter & Red Maize & Blue Maize \\
\hline Moisture (\%) & 11.92 & 11.32 \\
Crude fibre (\%) & 1.50 & 1.59 \\
Crude protein (\%) & 8.52 & 8.69 \\
Crude fat (\%) & 5.08 & 4.93 \\
Ash (\%) & 1.25 & 1.29 \\
Total carbohydrate (\%) & 71.73 & 72.18 \\
Reducing sugar (\%) & 2.97 & 3.05 \\
\hline
\end{tabular}

\section{Determination of the sprouted kernels percentage}

Although the germination percentage of the blue maize was only about two percentual point greater than that of the red maize $(91.4 \%$ and $89.3 \%$, respectively), the ANOVA (Table 3) showed significant difference between them ( $\mathrm{p}$-value $<0.001)$. Concerning the temperature, as it is shown in the Table 4 , the greatest germination values were at $20^{\circ} \mathrm{C}$, meanwhile the lowest were observed when the maize was germinated at $15^{\circ} \mathrm{C}$ ( $\mathrm{p}$-value $\left.<0.001\right)$. With respect to this Silva-Neta et al. (2015) tested 4 germination temperatures $\left(10,15,20\right.$, and $\left.25^{\circ} \mathrm{C}\right)$ and their results showed that for some of the tested varieties as the temperature rose, the germination percentage also increased; however, in some varieties it was observed a decrease of this value when germinating at $20^{\circ} \mathrm{C}$ in comparison to germination at $15^{\circ} \mathrm{C}$. Thus, the decrease in the germination percentage of the maize used in this research, when germinating at $25^{\circ} \mathrm{C}$ in comparison to the germination at $20^{\circ} \mathrm{C}$, could be associated to the 'Chalqueño' race itself.

In the mentioned research, Silva-Neta et al. (2015) obtained germination percentages from 86 to $100 \%$ when germinating at 20 and $25^{\circ} \mathrm{C}$. In addition, Zakeyeldinn et al. (2018) reported final germination percentages between 90.5 and 98 in five different hybrid maize varieties. Thus, the low germination percentages obtained in this research for 'Chalqueño' race maize could be related to a long storage, since it is reported that as the seed storage increases, both germination rate and germination index decrease (Garoma et al., 2017).

\section{Acrospire length}

As expected, the acrospire length increased as the germination time did, thereby being the 9-day malts having the longest acrospires; on the other hand, the 3-day malts were those with the shortest acrospires ( $\mathrm{p}$-value $<0.001)$. With reference to this, Evans et al. (2009), in a study about four different cereals, reported a significant relation between germination time and the acrospire vigour, showing a significantly increase in the growth of acrospire over the time. Concerning the germination temperature, the acrospire length increased as the temperature rose. So, the malts germinated at $25^{\circ} \mathrm{C}$ had the longest acrospires, followed by those germinated at $20{ }^{\circ} \mathrm{C}$, and finally the ones germinated at $15^{\circ} \mathrm{C}(\mathrm{p}$-value $<0.001)$. As for the maize colour, the red maize had longer acrospires than the blue maize ( $\mathrm{p}$-value $<0.001$ ), being their means lengths of 6.71 and $6.21 \mathrm{~cm}$, respectively. These results agree with those of Akinnuoye and Modi (2015), who reported longer shoot lengths when the germination temperature of maize increased from 20 to $30^{\circ} \mathrm{C}$. Similarly, Ennen and Jeschke (2020) reported higher shoot growth rates when maize germinated at higher temperatures. For example, the shoot growth rate when germinating at $15{ }^{\circ} \mathrm{C}$ was about 
Table 3: ANOVA results of the germination experiment

\begin{tabular}{|c|c|c|c|c|c|c|c|c|}
\hline \multirow[t]{3}{*}{ Factor or interactions of factors } & \multicolumn{8}{|c|}{ Response variables } \\
\hline & \multicolumn{2}{|c|}{ Germination percentage } & \multicolumn{2}{|c|}{ Acrospire length } & \multicolumn{2}{|c|}{ Diastatic power } & \multicolumn{2}{|c|}{ Malting yield } \\
\hline & F-Ratio & P-value & F-Ratio & P-value & F-Ratio & P-value & F-Ratio & P-value \\
\hline Maize & 63.59 & $<0.001$ & 38.98 & $<0.001$ & 23.89 & $<0.001$ & 385.09 & $<0.001$ \\
\hline Germination temperature (GT) & 32.13 & $<0.001$ & 4297.12 & $<0.001$ & 377.38 & $<0.001$ & 8599.32 & $<0.001$ \\
\hline Germination days & 5.31 & $<0.001$ & 1089.16 & $<0.001$ & 342.21 & $<0.001$ & 3068.08 & $<0.001$ \\
\hline Maize*GT & 16.77 & $<0.001$ & 5.90 & $<0.001$ & 4.81 & 0.0106 & 47.41 & $<0.001$ \\
\hline Maize*Germination days & 0.78 & 0.59 & 1.23 & 0.30 & 9.23 & $<0.001$ & 8.48 & $<0.001$ \\
\hline $\mathrm{GT}^{\star}$ Germination days & 4.15 & $<0.001$ & 141.03 & $<0.001$ & 6.19 & $<0.001$ & 166.04 & $<0.001$ \\
\hline Maize* ${ }^{*} T^{\star}$ Germination days & 2.73 & 0.004 & 2.46 & 0.008 & 4.23 & $<0.001$ & 3.76 & $<0.001$ \\
\hline
\end{tabular}

a) Bold numbers refer to those factors and/or interactions that resulted significant for the response variables

Table 4: Germination percentages of the red and blue maize at the three different germination temperatures

\begin{tabular}{lcccc}
\hline \multicolumn{5}{c}{${\text { Temperature }\left({ }^{\circ} \mathrm{C}\right)}$} \\
\hline Colour of maize & $\mathbf{1 5}$ & $\mathbf{2 0}$ & $\mathbf{2 5}$ & p-value \\
\hline Red & $87.03^{\mathrm{Bb}}$ & $90.89^{\mathrm{Ba}}$ & $89.98^{\mathrm{Aa}}$ & $<0.001$ \\
Blue & $91.29^{\mathrm{Ab}}$ & $92.77^{\mathrm{Aa}}$ & $90.39^{\mathrm{Ab}}$ & $<0.001$ \\
Average $^{(\mathrm{b})}$ & $89.16^{\mathrm{C}}$ & $91.83^{\mathrm{a}}$ & $90.19^{\mathrm{b}}$ & $<0.001$ \\
\hline
\end{tabular}

(a) Capital letters indicate subgroups for temperatures (columns), and lowercase letters indicate subgroups for maize colour (rows).

(b) Germination average of both maize colours, just considering the effect of the factor temperature

$0.3 \mathrm{~mm} /$ hour whereas it was around of $1.4 \mathrm{~mm} /$ hour when germinating at $30{ }^{\circ} \mathrm{C}$. The effect observed on the length acrospires could be due to both rate of plant growth and development depend upon temperature surrounding the plant (Hatfield \& Prueger, 2015), since all biological processes respond to it (Pietruszka \& Haduch-Sendecka, 2016). It has been reported that the speed of germination is driven by accumulated temperature, or degree-days (GRDC, 2016). In addition to this, some studies have shown that plants adjust their growth and development as a response to even small differences in temperature. The set of morphological and architectural changes induced by high ambient temperatures, below the heatstress, is collectively called thermomorphogenesis (Quint et al., 2016).

\section{Malting yield}

As it can be seen in Figs. 2 and 3, the malting yield decreased in both colour of maize malts as the germination time increased, being the 3-day germinated malts those with the highest, and the 9-day germinated malts those with the lowest malting yield ( $\mathrm{p}$-value $<0.001$ ). Regarding to this, Ndife et al. (2019) reported malting losses of $10.6 \%$ and $19.52 \%$ in maize malts germinated for three and five days, respectively. There are some other studies about malts of different cereals in which a malting yield decrease was reported over the time. For example, Lekjing and Venkatachalam (2020) reported a malting yield decrease in rice malts as the germination time increased. Olugbile et al. (2015) reported a malting yield of $77.86 \%$ in rice malts germinated for three days and $45.46 \%$ in malts germinated 12 days, which clearly showed a malting yield decrease over

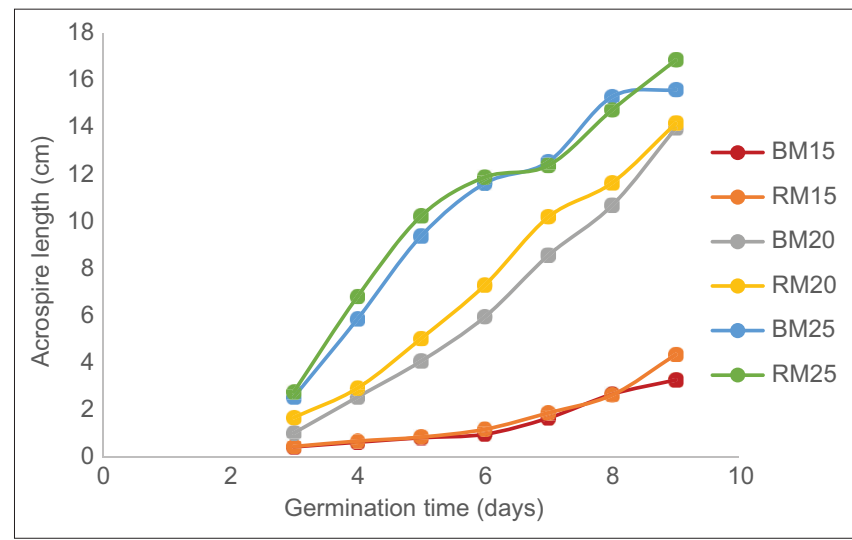

Fig 1. Effect of temperature and germination time on acrospire length of red and blue maize malts. The letters BM and RM refer to Blue Maize and Red Maize, respectively, and the numbers 15, 20, and 25 refer to the germination temperature.

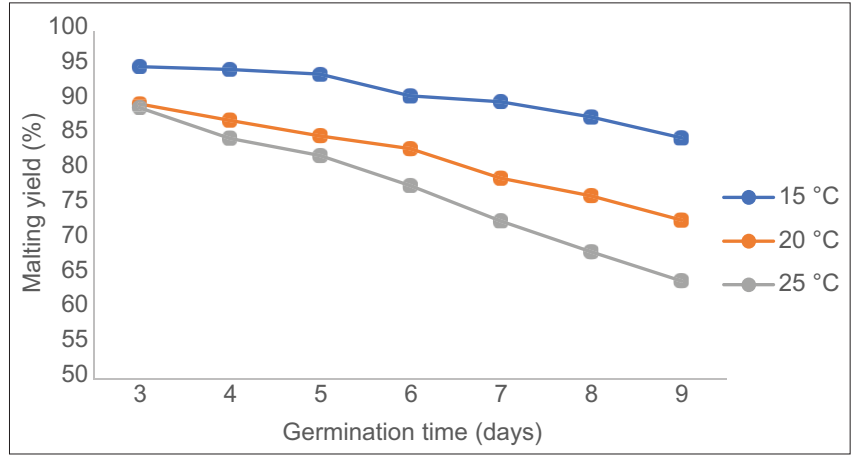

Fig 2. Effect of temperature and germination time on malting yield of red 'Chalqueño' race maize malts. The numbers 15, 20, and 25 refer to the germination temperature.

the germination time. Farzaneh et al. (2017) reported a malting yield of $86 \%$ in barley malts germinated for three days, which dropped until $78 \%$ in malts germinated for seven days. Eburuche et al. (2019) reported malting loss between $2 \%$ and $23 \%$ for both red and white sorghum malts, which increased as the germination time increased.

With respect to the germination temperature, the malting yield decreased as this factor increased. In this way, as it is shown in Figs. 2 and 3, the malting yield percentages of 
the malts germinated at $15{ }^{\circ} \mathrm{C}$ were significantly higher than those germinated at 20 and $25^{\circ} \mathrm{C}$, being this last one which had the lowest percentages ( $\mathrm{p}$-value $<0.001)$. A similar result was reported by Claver et al. (2010), for sorghum malts, who proposed a mathematical model in which was shown that, in addition to the germination time, any increase in temperature would significantly increase malting loss.

These drops in malting yield are mainly caused by metabolic activity during the germination process as starch is the main source of stored energy in the quiescent grains, and degradation of starch is essential for heterotrophic growth in the germinating seed (Vinje et al., 2015). It is reported that, during seed germination, the stored reserves support growth of the seedling until it becomes photosynthetically active. So, the high-molecular-weight reserves, like starch, contained within the seed storage organs are converted into easily transportable low-molecular-weight metabolites that are mobilized to the growing regions in support of the energy-producing and synthetic events therein (Derek, 2001).

As for maize colour, the blue maize malts had a higher malting yield than the red maize malts ( $\mathrm{p}$-value $<0.001$ ), whose values were $84.8 \%$ and $83.2 \%$, respectively. This difference could be related to the longer acrospires of the red maize germinated under some of the treatments (combination of temperature and germination time), as it is shown in Fig. 1.

\section{Correlation between the acrospire length and malting loss}

As it is shown in Fig. 4, the Pearson's correlation coefficient (r) was 0.96 , which indicates that malting loss was strongly related to the acrospire length, and as this latter increased, the former also did.

The obtained linear regression equation indicates that, under the conditions used in this experiment, the malting loss was at rate of $1.47 \%$ per $\mathrm{cm}$ of acrospire growth. Besides, the y-intercept indicates the malting loss that could be attributable to moisture loss in malt after kilning $(\approx 5 \%)$, in comparison to the initial moisture of raw maize $(11-12 \%)$.

\section{Linear calibration to calculate diastatic power}

Determination results of the diastatic power of different malts, through both methods, are shown in Fig. 5. As it can be seen, some variations were found in both methods, which could be attributed to errors in the determinations. However, it was observed a linearity between those, and the curve showed a correlation coefficient of 0.96 . This value is higher than that reported by Henry (1984), and it is within the range of correlations coefficients obtained by a group of 12 collaborators, who everyone performed a linear calibration between the Henry's method and the ASBC method, and whose values were between 0.91 and 0.99 (ASBC, 1990). It is important to mention that in the present work the range encompassed lower diastatic power values than in those cited studies. So that, the maize experimental malts fell within this. Therefore, the obtained equation, shown just below, was useful to convert the Henry's method units into Lintner degrees. In Table 5 is shown the diastatic power of some maize malts calculated by using the obtained equation.

$$
{ }^{\circ} L=\left[291.4 *\left(g \frac{\text { dextrose }}{l}\right)\right]-0.0348
$$

\section{Diastatic power}

Results showed that the diastatic power values of the maize malts maintained an increase from $3^{\text {rd }}$ day to $7^{\text {th }}$ day of germination at the three tested temperatures, and after the seventh day it was shown a decrease of these values (Fig. 6). Consequently, the greatest values for all experimental malts were observed on the seventh day of germination, regardless of the germination temperature ( $\mathrm{p}$-value $<$ 0.001). These results agree with those reported by Singh and Bains (1984), who studied the effect of alkali pre-

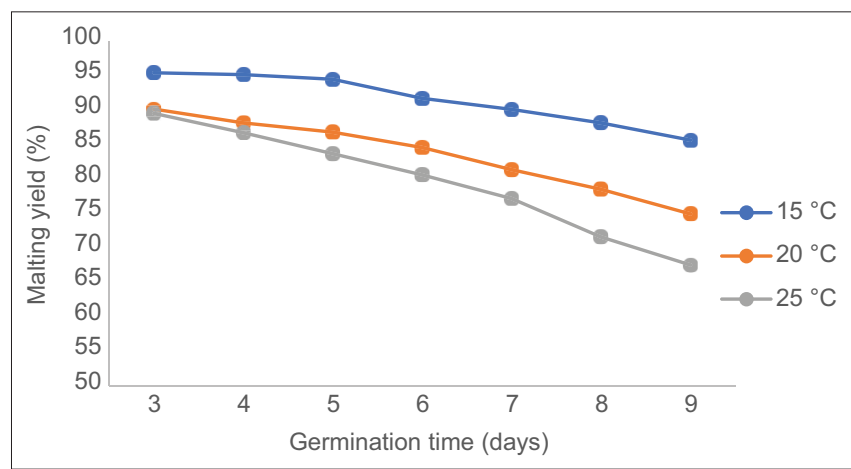

Fig 3. Effect of temperature and germination time on malting yield of blue 'Chalqueño' race maize malts. The numbers 15, 20, and 25 refer to the germination temperature.

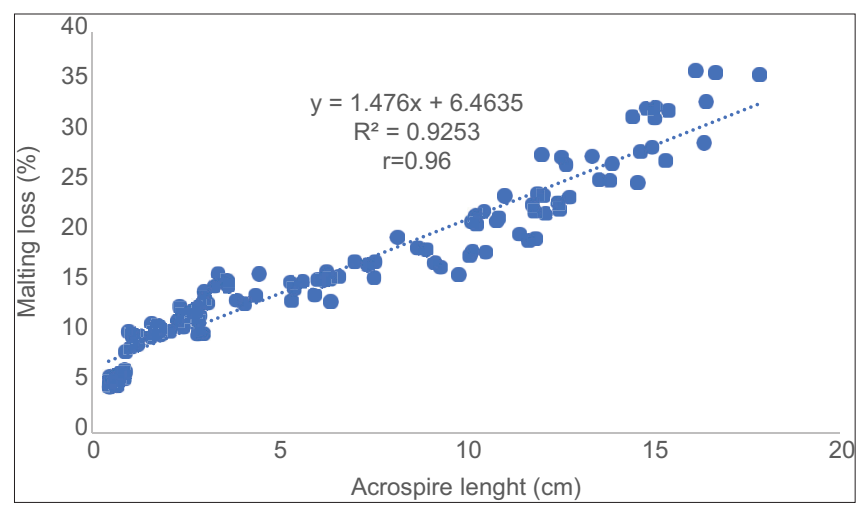

Fig 4. Linear regression of malting loss as a function of acrospire length . 
Table 5: Diastatic power of some experimental malts expressed as $\mathrm{g}$ of dextrose/l, as well as in ${ }^{\circ} \mathrm{L}$ (rounded to the nearest whole number) calculated by means of the obtained formula

Malt

$15^{\circ} \mathrm{RM}-6 \mathrm{D}$

$15^{\circ} \mathrm{RM}-7 \mathrm{D}$

$15^{\circ} \mathrm{BM}-6 \mathrm{D}$

$15^{\circ} \mathrm{BM}-7 \mathrm{D}$

$20^{\circ} \mathrm{RM}-6 \mathrm{D}$

$20^{\circ} \mathrm{RM}-7 \mathrm{D}$

$20^{\circ} \mathrm{BM}-6 \mathrm{D}$

$20^{\circ} \mathrm{BM}-7 \mathrm{D}$

$25^{\circ} \mathrm{RM}-6 \mathrm{D}$

$25^{\circ} \mathrm{RM}-7 \mathrm{D}$

$25^{\circ} \mathrm{BM}-6 \mathrm{D}$

$25^{\circ} \mathrm{BM}-7 \mathrm{D}$

(a) Numbers $15^{\circ}, 20^{\circ}$, and $25^{\circ}$ refer to the germination temperature in degrees Celsius ( $\left.{ }^{\circ} \mathrm{C}\right)$.(b) Letters BM and RM refer to Blue Maize and Red Maize,

respectively. (c) $6 \mathrm{D}$ and $7 \mathrm{D}$ refer to 6 and 7 days of germination, respectively

treatment of grains on some quality parameters of malts from two distinct maize varieties and found that the greatest diastatic power values of the malts were obtained when maize was germinated for seven days. In the same way, Farzaneh et al. (2017) reported both the highest enzymatic activity and diastatic power for barley malts germinated for seven days. On the other hand, the results of the present research differ from those reported by Iwouno and Ojukwu (2012), for malts of yellow Nigerian maize varieties, whose greatest values were reached on the fifth day of germination and showed values of about $30^{\circ} \mathrm{L}$. Also, the obtained results differ from those reported by Eneje et al. (2004), for malts of white and yellow Nigerian maize varieties, which their greatest diastatic power values were reached on the sixth germination day. Nevertheless, since the germination in the two last mentioned experiments lasted five and six days, respectively, and they were performed at different temperatures, the discrepancies with the results of this research could have been due to either differences in the metabolic properties among the maize varieties or to the differences in malting conditions. In other research about amylolytic enzymes, Helland et al. (2002) reported the maximum activity of $\alpha$-amylases when maize was germinated for seven days; whereas in another one about Nigerian maize cultivars, the highest $\alpha$-amylase activity was on the third day of germination, while the highest $\beta$-amylase activity was on the fifth day of germination (Awoyinka \& Adebawo, 2008).

With reference to germination temperature, it was observed an increase in the diastatic power values as the germination temperature was increased (Fig. 6). In such way, the greatest values were obtained when germinating at $25{ }^{\circ} \mathrm{C}$ for both maize colours ( $\mathrm{p}$-value $<0.001)$. This temperature falls within the optimum temperature of maize, which is reported between $24^{\circ} \mathrm{C}$ and $28^{\circ} \mathrm{C}$ (Hatfield and Prueger,

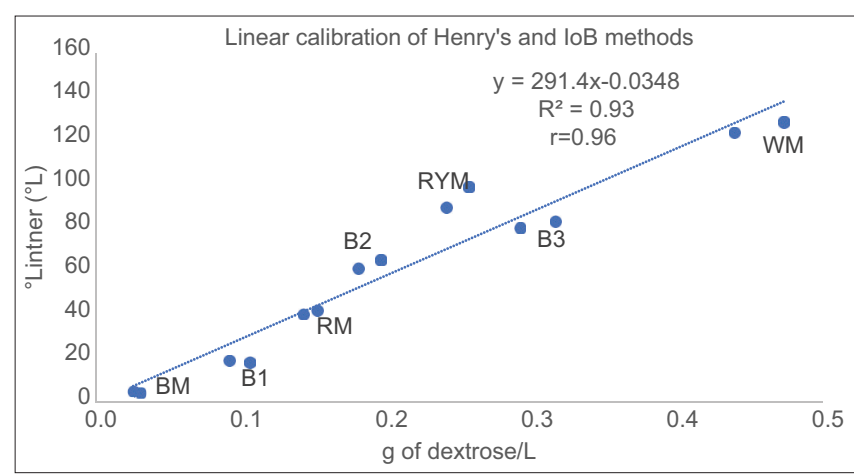

Fig 5. Correlation curve of the IoB and Henry's method $\mathrm{BM}=$ Blue-maize malt; $\mathrm{B} 1=$ Caramel barley malt; $\mathrm{RM}=$ Red maize malt; $\mathrm{B} 2=$ Vienna malt $\mathrm{B} 3=$ Pale Ale malt; $\mathrm{RYM}=$ Rye malt; $\mathrm{WM}=\mathrm{Wheat}$ malt

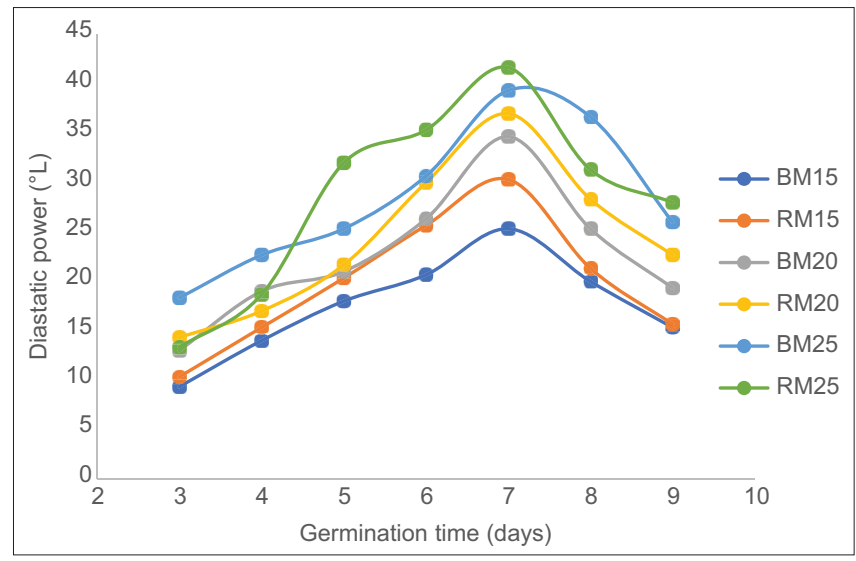

Fig 6. Effect of temperature and germination time on diastatic power of red and blue 'Chalqueño' race maize malts. The letters BM and RM refer to Blue Maize and Red Maize, respectively, and the numbers 15, 20 , and 25 refer to the germination temperature.

2015). Aniche and Okafor (1989), reported a similar effect on the diastatic power of rice malts, whose values had a rapid increase when the germination temperature was rising from 22 to $28{ }^{\circ} \mathrm{C}$. Conversely, the lowest diastatic power values were obtained when the maize was germinated at $15^{\circ} \mathrm{C}$. In relation to this, it is reported that low temperature tends to slow synthesis of enzymes, their diffusion through the endosperm and their action (Lewis \& Young, 2001).

With respect to the colour, the red-maize malts reached greater values of diastatic power than the blue ones when germinating at $15^{\circ} \mathrm{C}$ and $20^{\circ} \mathrm{C}(\mathrm{p}$-value $<0.001)$, but there was no significant difference at $25^{\circ} \mathrm{C}$ (Fig. 6). Regarding the blue maize varieties, Meußdoerffer and Zarnkow (2009) reported a diastatic power of $72^{\circ} \mathrm{WK}$ (about $25^{\circ} \mathrm{L}$ ) for malts germinated for six days at $15^{\circ} \mathrm{C}$. In the case of redmaize malts, it was not found any report of neither diastatic power nor other malt properties for these.

Considering the three involved factors, and since there was no significant difference between the malts, both red and blue maize malts germinated during seven days at $25^{\circ} \mathrm{C}$ had 


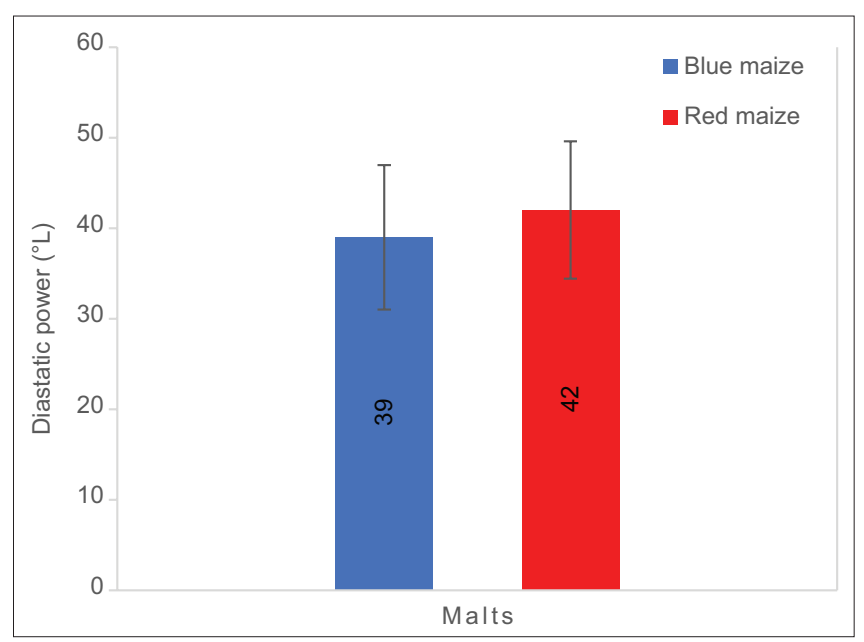

Fig 7. Diastatic power of blue and red maize malts germinated for 7 days at $25^{\circ} \mathrm{C}$

the greatest diastatic power, these values were 42 and $39^{\circ} \mathrm{L}$, respectively (Fig. 7). This means that both malts have about the minimum diastatic power to convert their own starch, which is $40^{\circ} \mathrm{L}$ (Farber \& Barth, 2019). In counterpart, the lowest values were obtained by the malts of both maize colour when malting three days at $15^{\circ} \mathrm{C}$, whose value was 9 and $10^{\circ} \mathrm{L}$ for blue and red, respectively.

The greater diastatic power values of the 'Chalqueño' race maize malts, compared to those reported from other varieties, could be related, besides to the mentioned malting conditions, to the larger grain size of this race, since in a research about barley malts, conducted by Agu et al. (2007), it was found a positive correlation between the proportion of large-size grains contained in a malt and its diastatic power.

It is reported that maize have adequate activity of $\alpha$-amylases (Dziedzoave et al., 2010), and they are responsible for most of amylolytic activity in maize seeds. Also, maize malts have relatively low activity of $\beta$-amylases (Dziedzoave et al., 2010; Evangelista-Oliveira et al, 2013), which are considered the most important enzymes for diastatic power in malts (Arends et al., 1995). However, Awoyinka and Adebawo (2008) reported that some maize cultivars were high in alpha amylolytic activity and some others were high in beta amylolytic activity. Thus, based on this research, both blue and red maize belonging to the 'Chalqueño' race could be high- $\beta$-amylase-activity maize cultivars, which would be responsible for their higher diastatic power in comparison to other maize cultivars. Nevertheless, it is needed a research to confirm this.

\section{CONCLUSIONS}

There was a positive effect on the diastatic power of the maize malts when the germination temperature was increased. However, this factor did not modify the germination time in which the maximum values of diastatic power of the malts were reached. Likewise, under the mentioned optimum conditions of malting, according to the reported minimum diastatic power value for a malt, the malts obtained from blue and red 'Chalqueño' race maize are capable to convert their own starch. Nevertheless, it is necessary to carry out more studies in which other malting factors are considered, such as grain moisture, in order to control the acrospire growth and thus reduce malting loss.

\section{ACKNOWLEDGEMENTS}

The authors thank the CONACYT for the scholarship (2017-2020 period) granted to Miguel A. HernándezCarapia for his $\mathrm{PhD}$ in the Biotechnology Posgraduate Program at the Universidad Autónoma Metropolitana, México (635326/570375).

\section{Conflict of interest}

The authors declare there are no conflicts of interest.

\section{REFERENCES}

MacLeod, L. and E. Evans. 2016. Malting. Reference Module in Food Science. Elsevier, Amsterdam, Netherlands, pp. 1-11.

Ribeiro, G. O. Jr., M. L. Swift and T. A. McAllister. 2016. Effect of diastatic power and processing index on the feed value of barley grain for finishing feedlot cattle. J. Anim. Sci. 94: 3370-3381.

Farber, M. and R. Barth. 2019. Raw Materials: Malt, in Mastering Brewing Science: Quality and Production. John Wiley and Sons Inc., USA, p. 146.

Looseley, M. O., M. Bayer, H. Bull, L. Ramsay, W. Thomas, A. Booth, C. De La Fuente-Canto, J. Morris, P. E. Hedley and J. Russell. 2017. Association mapping of diastatic power in UK winter and spring barley by exome sequencing of phenotypically contrasting variety sets. Front. Plant Sci. 8: 1566.

Henry, R. J. 1984. A rapid method for the determination of diastatic power. J. Inst. Brew. 90: 37-39.

Chaudhary, D., S. Kumar and S. Langyan. 2014. Nutritive value of maize: Improvements, applications, and constraints. In: Maize: Nutrition Dynamics and Novel Uses. Springer, India. pp. 11, 135, 139.

Iwouno, J. O. and M. Ojukwu. 2012. Effects of experimental variables on the malting quality of Nigerian yellow maize (Zea mayz), farz 27 variety. Afr. J. Food Sci. Technol. 3: 252-259.

Meußdoerffer, F. and M. Zarnkow. 2009. Starchy raw materials. In: M. E. Hans (Ed.), Handbook of Brewing. Eßlinger H. Wiley-VCH, Germany, pp. 56, 57, 64

Vielle-Calzada, J. P. and J. Padilla. 2009. The Mexican landraces: Description, classification and diversity. In: Handbook of Maize: Its Biology. Springer, New York, pp. 543-561.

Herrera-Cabrera, B. E., F. Castillo-González, J. J. Sánchez-González, J. M. Hernández-Casillas, R. A. Ortega-Pazkca and M. MajorGoodman. 2004. Diversity of Chalqueño maize. Agrociencia. 38 : 191-206.

Arellano-Vázquez, J. L., I. Rojas-Martínez and 
G. F. Gutiérrez-Hernández. 2014. Varieties of blue maize Chalqueño, selected for multiple characters and yield stability. Rev. Mexicana Cienc. Agric. 5: 1469-1480.

Eneje, L. O., E. O. Ogu, C. U. Aloh, F. J. Odibo, R. C. Agu and G. H. Palmer. 2004. Effect of steeping and germination time on malting performance of Nigerian white and yellow maize varieties. Process Biochem. 39: 1013-1016.

Awoyinka, O. A. and O. O. Adebawo. 2008. Influence of malting time on $\alpha$ and $\beta$ Amylases secretion in Nigerian amylolytic maize cultivars. Afr. J. Agric. Res. 3: 7-12.

Romero-Medina, M. A., M. Estarrón-Espinosa, J. R. Verde-Calvo, M. Lelièvre-Desmas and H. B. Escalona-Buendía. 2020. Renewing traditions: A sensory and chemical characterisation of Mexican pigmented corn beers. Foods. 9: 886.

Flores-Calderón, A. M. D., H. Luna, H. B. Escalona-Buendía and J. R. Verde-Calvo. 2017. Chemical characterization and antioxidant capacity in blue corn (Zea mays L.) malt beers. J. Inst. Brew. 123: 506-518.

Verde-Calvo, J. R., H. B. Escalona-Buendía, N. N. Cruz-Rodríguez and M. A. Romero-Medina. 2019. Proceso para la elaboración de cerveza antioxidante a base de maíz malteado azul y rojo. Mexico Patent. 2019: 365910.

NOM-116-SSA1. 1994. Bienes y Servicios. Determinación de Humedad en Alimentos por Tratamiento Térmico. Método por Arena o Gasa. Diario Oficial de la Federación, Mexico.

NMX-F-613-NORMEX. 2017. Alimentos-determinación de Fibra Cruda en Alimentos-Método de Prueba. Diario Oficial de la Federación, Mexico.

NMX-F-608-NORMEX. 2011. Alimentos-Determinación de Proteínas en Alimentos-método de Ensayo. Diario Oficial de la Federación. Mexico, 2011.

NOM-086-SSA1. 1994. Bienes y Servicios. Alimentos y Bebidas no Alcohólicas con Modificaciones en su Composición. Diario Oficial de la Federación, Mexico.

NMX-F-607-NORMEX. 2013. Alimentos-determinación de Cenizas en Alimentos-Método de Prueba. Diario Oficial de la Federación, Mexico.

Ramdath, D. D., L. Zhan-Hul, P. L. Maharaj, J. Winberg, Y. Brummer and A. Hawke. 2020. Proximate analysis and nutritional evaluation of twenty Canadian lentils by principal component and cluster analyses. Foods. 9: 1-16.

Deivasigamani, S. and C. Swaminathan. 2018. Evaluation of seed test weight on major field crops. Int. J. Res. Stud. Agric. Sci. 4: 8-11.

Saba, S. J., S. A. Kamal, M. Sadegh, T. T. Avishan and G. Alireza. 2014. Effects of elevated temperatures on seed germination and seedling growth in three medicinal plants. Int. J. Agric. Crop Sci. 7: 173-177.

Dahiya, R., R. B. Yadav, B. S. Yadav and R. Yadav. 2018. Quality characteristics of pearl millet malt as affected by steeping temperature and germination period. Qual. Assur. Saf. Crop. Foods. 10: 41-50.

Odo, M., P. Okorie, O. Ikegwu and M. Kalu. 2016. Malting potentials of hybrid and local varieties of rice. Asian J. Agric. Food Sci. 4: 146-151.

ASBC. 2004. Methods of Analysis. Malt Method 6: Diastatic Power. American Society of Brewing Chemists, St. Paul, MN, USA.

Anon. 1982. Recommended Methods Of Analysis. Institute of Brewing, London.

Home, S. and R. Sharpe. 2007. Revision of EBC Method 4.12 for Diastatic Power. Eur. Brewery Convention. 113: 337.

NCSS. 2020 Statistical Software. NCSS, LLC. Kaysville, Utah, USA.
Peña-Betancourt, S. D., R. Gutiérrez-Tolentino, B. Schettino. 2017. Proximate composition, fatty acid profile and mycotoxin contamination in several varieties of Mexican maize. Food Nutr Sci. 8: 865-872.

Sánchez-Madrigal, M. A., C. O. Meléndez-Pizarro, F. Martínez-Bustos, M. G. Ruiz-Gutiérrez, A. Quintero-Ramos, R. Márquez-Meléndez, D. Lardizábal-Gutiérrez and K. Campos-Venegas. 2014. Structural, functional, thermal and rheological properties of nixtamalised and extruded blue maize (Zea mays L.) flour with different calcium sources. Int. J. Food Sci. Technol. 49: 578-586.

Adeniyi, O. O. and O. S. Ariwoola. 2019. Comparative proximate composition of maize (Zea mays L.) varieties grown in southwestern Nigeria. Int. Ann. Sci. 7: 1-5.

Sulewska, H., K. Śmiatacz, G. Szymańska, K. Panasiewicz, H. Bandurska and R. Głowicka-Wołoszyn. 2014. Seed size effect on yield quantity and quality of maize (Zea mays L.) cultivated in South East Baltic region. Zemdirbyste. 101: 35-40.

Agama-Acevedo, E., Y. Salinas-Moreno, G. Pacheco-Vargas and L. A. Bello-Pérez. 2011. Physical and chemical characteristics of blue corn from two races: Starch morphology. Rev. Mex. Cienc. Agric. 2: 317-329.

Rocandio-Rodríguez, M., A. Santacruz-Varela, L. Córdova-Téllez, H. López-Sánchez, F. Castillo-González, R. Lobato-Ortiz, J. J. García-Zavala and R. Ortega-Paczka. 2014. Morphological and agronomic characterization of seven maize races from the highlands of Mexico. Rev. Fitotec. Mex. 37: 351-361.

Silva-Neta, I. C., E. V. Pinho, A. D. Veiga, R. G. Pinho, R. M. Guimarães, F. Caixeta, H. O. Santos and T. L. Marques. 2015. Expression of genes related to tolerance to low temperature for maize seed germination. Gen. Mol. Res. 14: 2674-2690.

Zakeyeldinn, E. A., M. A. Mustafa, C. Jinghua and T. Zenda. 2018. Germination of corn (Zea Mays L.) cultivars seed and its relationship to field performance under semi-arid conditions. IOSR J. Agric. Vet. Sci. 11: 32-40.

Garoma, B., T. Chibsa, T. Keno and Y. Denbi. 2017. Effect of storage period on seed germination of different maize. J. Nat. Sci. Res. 7: 2224-3186

Evans, C. E. and O. A. Monday. 2009. Predicting $\alpha$-amylase yield and malt quality of some sprouting cereals using $2^{\text {nd }}$ order polynomial model. Afr. J. Biochem. Res. 3: 288-292.

Akinnuoye, D. B. and A. T. Modi. 2015. Germination characteristics of SC701 maize hybrid according to size and shape at different temperature regimes. Plant Prod. Sci. 18: 514-521.

Ennen, R. and M. Jeschke. 2020. Soil temperature and corn emergence. Agronomy Research Summary. Corteva Agrisci. 28-32.

Hatfield, J. L. and J. H. Prueger. 2015. Temperature extremes: Effect on plant growth and development. Weather Climate Extremes. 10: 4-10.

Pietruszka, M. and A. Haduch-Sendecka. 2016. Effective diffusion rates and cross-correlation analysis of "acid growth" data. Acta Physiol. Plant. 38: 53.

GRDC. 2016. Wheat: Plant Growth and Physiology. Grain Research and Development Corporation, pp. 1-9.

Quint, M., C. Delker, K. A. Franklin, P. A. Wigge, K. J. Halliday and M. van Zanten. 2016. Molecular and genetic control of plant thermomorphogenesis. Nat. Plants. 2: 15190.

Ndife, J., C. U. Nwokedi and F. U. Ugwuona. 2019. Optimization of malting and saccharification in the production of malt beverage from maize. Niger. J. Agric. Food Environ. 15: 134-141.

Lekjing, S. and K. Venkatachalam. 2020. Effects of germination time and kilning temperature on the malting characteristics, 
biochemical and structural properties of HomChaiya rice. RSC Adv. 10: 16254-16265.

Olugbile, A. O., A. O. Abadina, A. O. Atanda, O. B. Omemu and S. O. A. Olatope. 2015. Physicochemical changes and diastatic activity associated with germination of "Boromo", a paddy rice variety from western Nigeria. J. Food Process. Preserv. 39: 116122.

Farzaneh, V., A. Ghodsvali, H. Bakhshabadi, Z. Zare and I. S. Carvalho. 2017. The impact of germination time on some selected parameters through malting process. Int. J. Biol. Macromol. 94: 663-668.

Eburuche, O. B., R. N. Attaugwu and H. E. Ufondu. 2019. Composition and hardness of malting red and white kaffir sorghum [Sorghum bicolor (L.) Moench] dried under the sun. J. Food Sci. Technol. 56: 3513-3523.

Claver, I. P., H. Zhang, Q. Li, H. Zhou and K. Zhu. 2010. Optimized conditions of steeping and germination and their effect on sorghum [Sorghum bicolor (L.) Moench] composition. Pak. J. Nutr. 9: 686-695.

Vinje, M. A., S. H. Duke and C. A. Henson. 2015. Comparison of factors involved in starch degradation in barley germination under laboratory and malting conditions. J. Am. Soc. Brew Chem. 73: 195-205.

Derek, J. 2001. Seed Germination and Reserve Mobilization. Encyclopaedia of Life Sciences. Nature Publishing Group, Berlin, Germany, pp. 1-7.

ASBC.1990. Diastatic Power (Rapid Method). J. Am. Soc. Brew
Chem. 48: 143-145.

Singh, T. and G. S. Bains. 1984. Malting of corn: Effect of Variety, Germination, Gibberellic Acid, and Alkali Pretreatments. J. Agric. Food Chem. 32: 346-348.

Helland, M. H., T. Wicklund and J. A. Narvhus. 2002. Effect of germination time on alpha-amylase production and viscosity of maize porridge. Food Res. Int. 35: 315-321.

Aniche, N. G and N. Okafor. 1989. Studies on the effect of germination time and temperature on malting of rice. J. Inst. Brew. 95: 165-167.

Lewis, M. J. and T. W. Young. 2001. Malting Biochemistry, in Brewing. Springer Books, Berlin, Germany, pp. 191-204.

Agu, R. C., J. M. Brosnan, T. A. Bringhurst, G. H. Palmer and F. R. Jack. 2007. Influence of corn size distribution on the diastatic power of malted barley and its impact on other malt quality parameters. J. Agric. Food Chem. 55: 3702-3707.

Dziedzoave, N. T., A. J. Graffham, A. Westby and G. Komlaga. 2010. Comparative assessment of amylolytic and cellulolytic enzyme activity of malts prepared from tropical cereals. Food Control. 21: 1349-1353.

Evangelista-Oliveira, G., R. Garcia-Von Pinho, T. De Andrade, E. V. De Resende-Von Pinho, C. Donizete-Dos Santos and A. Delly-Veiga. 2013. Physiological quality and amylase enzyme expression in maize seeds. Cienc. Agrotec., Lavras. 37: 40-48.

Arends, A. M., G. P. Fox, R. J. Henry, R. J. Marschke and M. H. Symons. 1995. Genetic and environmental variation in the diastatic power of Australian barley. J. Cereal Sci. 21: 63-70. 